\title{
Penentuan Magnitudo Gempa Bumi Dengan Menganalisis Amplitudo Anomali Manetik Prekusor Gempa Bumi Dan Jarak Hypocenter
}

\author{
Adhitama Rachman, Amien Widodo, Juan Pandu GNR \\ Departemen Teknik Geofisika, Fakultas Teknik Sipil dan Perencanaan, Institut Teknologi Sepuluh \\ Nopember (ITS) \\ e-mail: tama.rachman@gmail.com
}

\begin{abstract}
Abstrak-Gempabumi adalah peristiwa bergetarnya bumi akibat pelepasan energi di dalam bumi secara tiba-tiba yang ditandai dengan patahnya lapisan batuan pada kerak bumi. Akumulasi energi penyebab terjadinya gempabumi dihasilkan dari pergerakan lempeng-lempeng tektonik. Energi yang dihasilkan dipancarkan kesegala arah berupa gelombang gempabumi sehingga efeknya dapat dirasakan sampai ke permukaan bumi. Dikarenakan munculnya gempabumi secara tiba-tiba, maka tidak dapat dihindari adanya kerugian secara materi hingga adanya korban jiwa. Akan tetapi saat ini hal tersebut bisa saja dihindari dikarenakan saat ini sudah ada studi yang membahas prekursor gempabumi. Dengan studi ini kita dapat mengetahui kapan, dimana, dan seberapa besar magnitudo suatu gempabumi dengan menganalisis anomali magnetik. Sehingga secara tidak langsung dengan mengetahui anomali magnetik, magnitudo suatu gempabumi dapat diketahui. Anomali magnetik dioalah sehingga menghasilkan amplitudo polarisasi $\mathrm{Z} / \mathrm{H}$ yang mana amplitudo inilah yang akan menjadi salah satu variable dalam penentuan magnitudo suatu gempabumi. Variabel lain yang digunakan adalah jarak hypocenter suatu gempabumi dengan stasiun pengamatan BMKG yang terletak di Kupang. Didapatkan hasil persamaan

$\operatorname{Mag}=4,36+0,0805 \frac{Z}{H}-0,00201$ Hypo dengan nilai error selisih hasil $\pm 0.3 \mathrm{M}$.
\end{abstract}

Kata Kunci-Gempabumi, Prekursor Gempabumi, Polarisasi Z/H.

\section{PENDAHULUAN}

$\mathrm{S}$ EPERTI yang telah diketahui bahwa permukaan bumi selalu bergerak. Hal ini dikarenakan adanya peristiwa tektonik. Pergerakan permukaan bumi tidaklah menentu sehingga terkadang terdapat peristiwa penumbukkan antara satu lempeng dengan lempeng lainnya. Hal ini lah yang menyebabkan terjadinya gempa bumi. Selain itu pergerakan lempeng juga menyebabkan stress pada batuan. Batuan yang terus menerus mendapat stress lama-lama akan patah hal ini terjadi apabila batas kemampuan batuan untuk menahan stress telah terlampaui. Patahan inilah yang nantinya akan menjadi salah satu faktor penyebab terjadinya gempa bumi. Dan patahan ini menyebabkan material-material dalam batuan mengalami perubahan, misalnya adanya anomali medan magnet, gravitasi, kandungan air, dan sifat radio aktif.
Dikarenakan kemunculan gempa yang secara tiba-tiba, menyebabkan kerugian material bahkan hingga dapat menghilangkan nyawa. Maka dari itu hal yang diperlukan untuk menghindari hal-hal yang merugikan dibutuhkan adanya early warning systems agar masyarakat siap dan tau apa yang harus dilakukan untuk menghindari bencana gempa tersebut. Saat ini terdapat teori yang sedang dikembangkan untuk mengetahui kapan terjadinya suatu gempa bumi dengan meneliti perubahan nilai kemagnitan batuan pada suatu daerah. Karena seperti yang telah saya utarakan sebelumnya bahwa pergerakan lempeng dapat menimbulkan stress yang mengakibatkan terjadinya suatu patahan yang dapat merubah material-material batuan termasuk nilai kemagnitan suatu batuan. Pada penelitian sebelumnya dengan menggunakan perubahan nilai kemagnitan batuan dapat menentukan waktu terjadinya gempabumi dengan kekuatan magnitudo $>5 \mathrm{M}$.

Oleh karena itu penulis ingin membahas tentang precursor gempa bumi/prediksi gempa bumi. Pada studi ini penulis menggunakan metode magnet sebagai study tentang prekursor gempa bumi. Membahas mengenai seberapa besar gempa yang akan terjadi dan waktu terjadinya dengan menganalisis amplitudo yang didapat dari anomaly medan magnet serta jarak hypocenter. Karena berdasarkan hasil monitoring sebelum gempa bumi terjadi memang ada beberapa tanda yang menunjukan gejala anomaly tertentu, salah satunya adalah anomaly pada nilai medan magnet. Dan data yang digunakan untuk penelitian ialah data pada daerah Kupang, Nusa Tenggara Timur.

\section{TINJAUAN PUSTAKA}

\section{A. Polarisasi $\mathrm{Z} / \mathrm{H}$}

Metode polarisasi rasio sZ/zH digunakan untuk menentukan waktu mula (onset time). Komponen $\mathrm{Z}$ adalah komponen vertikal dalam instrumen Magnetograph yang dapat merespon dengan baik aktifitas seismogenik, begitu juga sebaliknya pada komponen $\mathrm{H}$ (Horizontal) dapat merespon dengan baik aktivitas geomagnet global. Penentuan onset time dapat ditentukan apabila rasio sZ/sH melewati batas dari standar deviasisinya, sehingga dapat ditentukan sebagai anomali emisi ULF. 


\section{B. Hubungan Gelombang Anomali ULF dengan Gempabumi}

Saat ini diketahui terdapat tiga model yang diketahui untuk mekanisme generasi gelombang ULF seperti pada gambar 1 . [1] dan [2] mempertimbangkan model pertama berdasarkan microfracturing. Sebelum gempa bumi (EQ), mereka telah mengusulkan agar muatan dibuat di dinding bukaan retak dan gangguan EM dapat dikaitkan dengan keadaan relaksasi muatan. Model kedua, diusulkan oleh [3], menggambarkan pecahnya kompartemen tertutup dari sesar yang menghasilkan perubahan tekanan pori yang cepat dan aliran cairan yang tidak stabil yang berakibat pada generisasi sinyal magnetik transien dengan efek elektrokinetik. [4][5][3]. Akhirnya, model ketiga untuk mekanisme pembangkitan ULF (selain dari emisi ULF) adalah perubahan konotivitas geo-listrik di litosfer di zona fokus EQ, yang menyebabkan perubahan amplitudo gelombang elektromagnetik yang dipantulkan.

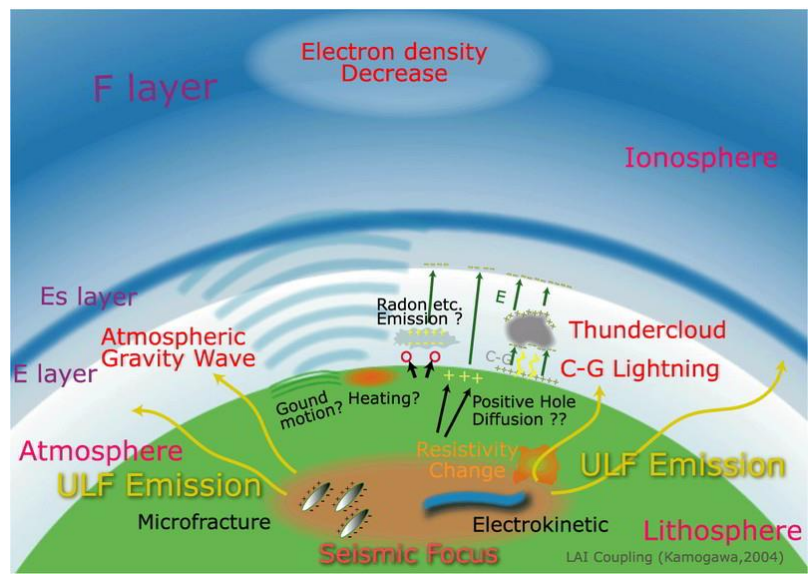

Gambar 1. Tiga Model dari anomali ULF berasosiasi dengan gempa bumi.

\section{Gelombang ULF dan Litosfer-Atmosfer-Ionosfer (LAI) Coupling}

Ada tiga jenis anomali gelombang ULF yang terkait dengan gempa besar. Dua jenis pertama adalah emisi ULF yang disebut, yang didorong oleh efek microfracturing dan elektrokinetik di wilayah fokus seismik. Yang ketiga adalah perubahan polarisasi ULF (dan power) yang disebabkan oleh formasi dari daerah konduktif di litosfer. Di sisi lain, amplitudo gelombang ULF diamati di lapangan menunjukkan variasi musiman, waktu setempat, dan latitudinal [6], yang merupakan fungsi parameter pada angin matahari, magnetosfer, ionosfer, dan litosfer, dan Dapat dinyatakan dalam persamaan berikut [7]:

$$
A=B f(L T) \sigma
$$

Dimana A, B, f, dan $\sigma$ adalah amplitudo ULF yang diamati di permukaan, parameter gelombang sumber pada angin matahari dan / atau magnetosfer, ketergantungan waktu lokal di ionosfer, dan faktor penguat pada Litosfer, masing-masing. Faktor penguat untuk emisi ULF, yaitu model pertama dan kedua di Bagian 2, harus proporsional dengan besarnya gempa bumi dan berbanding terbalik dengan jarak antara observatorium dan pusat gempa bumi.

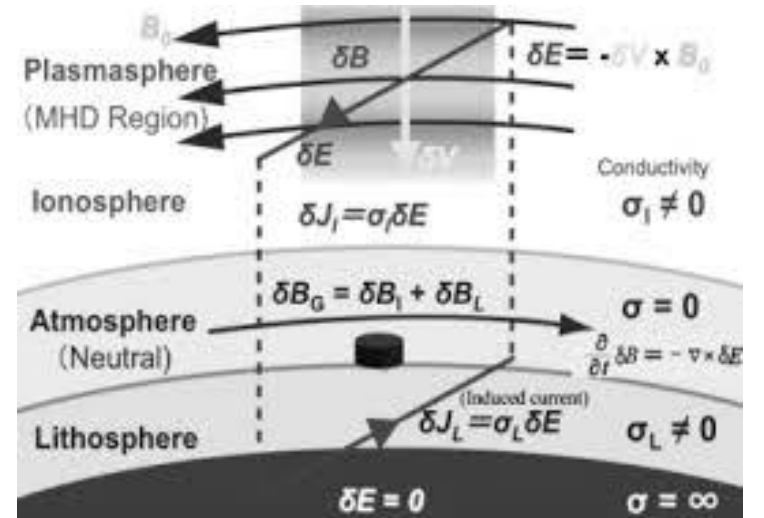

Gambar 2. Elektromagnetik coupling dari gelombang ULF di plasmasferionosfer-atmosfer-litosfer.

Gambar. 2. menunjukkan diagram skematik kopling elektromagnetik gelombang ULF di atmosfer plasmasferionosfer-atmosfir-litimeter di dekat ekuator pemukul magnetik. Medan listrik $(\delta E)$ gelombang ULF eksternal di plasmasfer (yaitu, daerah MHD) menimbulkan arus ionosfer $\left(\delta J_{l}\right)$, yang menghasilkan medan magnet $\left(\delta B_{I}\right)$ di tanah. Medan magnet kejadian ini menghasilkan arus yang diturunkan $\left(\delta J_{L}\right)$ di bawah tanah. Arus yang diinduksi juga menghasilkan medan magnet tercermin $\left(\delta B_{L}\right)$ di tanah. Variasi medan magnet total di lapangan menjadi $\delta B_{G}=\delta B_{I}+\delta B_{L}$. Faktor amplifikasi dari Persamaan (1) sama dengan $\left(\delta B_{G} / \delta B_{I}=1.0+\delta B_{L} / \delta B_{I}\right)$ untuk model ketiga di Bagian 2. Rasio asal ionosferal (kejadian $\delta B_{I}$ ) terhadap lithospheric one (tercermin $\delta B_{L}$ ) adalah fungsi dari konduktivitas listrik $\left(\sigma_{I}, \sigma_{L}\right)$ di ionosfer dan litosfer dan gelombang ULF yang menginduksi periode $(T)$. Jika konduktivitas listrik di litosfer tidak terbatas, medan magnet yang dipantulkan sama dengan bidang kejadian, dan sebagai hasilnya, amplitudo tingkat latar belakang diukur dua kali dari medan magnet kejadian (Merzer dan Klemperer, 1997).

\section{METODOLOGI}

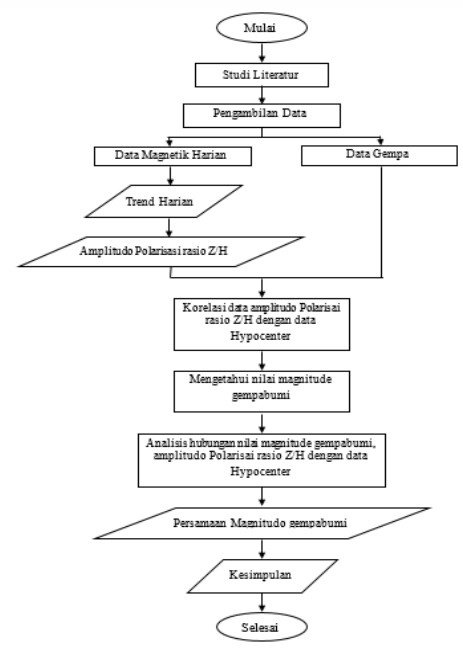

Gambar 3. Skema Kerja Penelitian 


\section{HASIL DAN PEMBAHASAN}

\section{A. Penentuan Prekursor Tiap Event Gempa}

Dalam penentuan pekursor tiap event gempa, terdapat beberapa analisis yang harus dilakukan terlebih dahulu. Analisis ini dapat dilakukan apabila sudah ada hasil pengolahan data magnetik yang didapat dan dihasilkannya amplitude polarisasi $\mathrm{Z} / \mathrm{H}$, nilai Azimuth, dan analisis Spektrum.

Analisis pertama adalah pemilihan nilai azimuth dengan data gempa yang diteliti, sebagai contoh penulis memilih satu event gempa untuk diteliti yaitu event gempa pada tanggal 5 januari 2017 (Gambar 4). Dalam pemlihan azimuth yang harus diperhatikan adalah arah serta waktu kapan munculnya nilai azimuth, yang mana nilai azimuth yand dapat digunakan adalah dalam kurun waktu 30 hari sebelum event gempa terjadi, sehingga pemilihan azimuth dimulai dari tanggal 6 Desember dan harus melebihi dari nilai standar deviasi pada bulannya. Penulis memilih 4 azimuth yang sesuai dengan ketiga kriteria tersebut yang dapat dilihat pada Gambar 5.

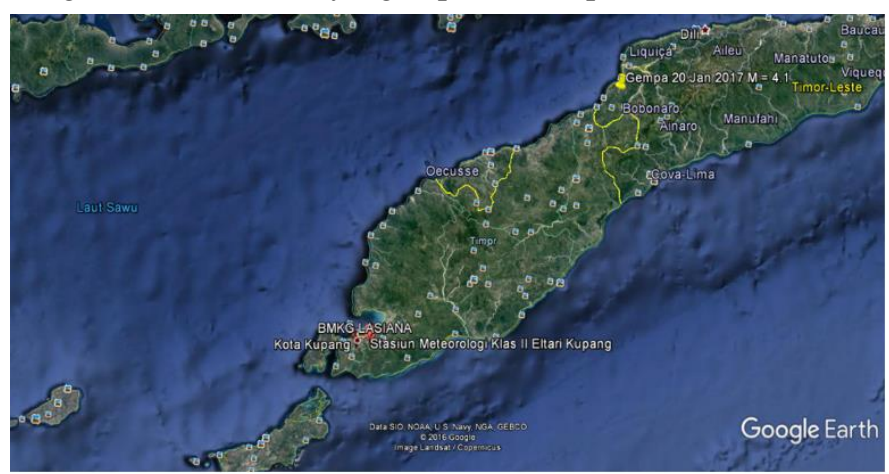

Gambar 4. Peta titik event gempa 5 Januari 2017

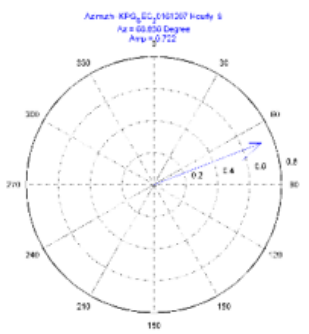

(a)

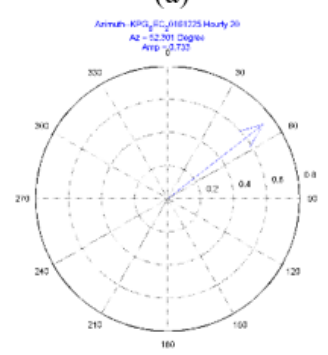

(c)

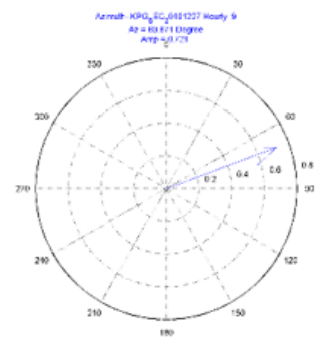

(b)

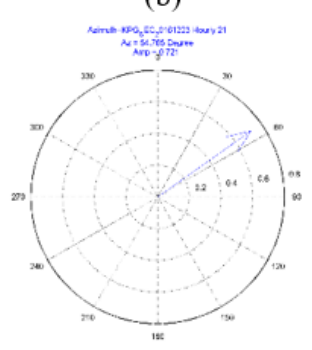

(d)
Gambar 5. Azimuth 7 Desember (a), Azimuth 27 Desember (b), Azimuth 25 Desember (c), Azimuth 23 Desember (d)

Setelah dipilihnya azimuth, dilanjutkan dengan melihat data spektrum azimuth yang telah dipilih. Apabila data spektrum tersebut kurang baik maka akan timbul kemungkinan adanya error dalam mengeluarkan nilai azimuth pada tanggal tersebut.

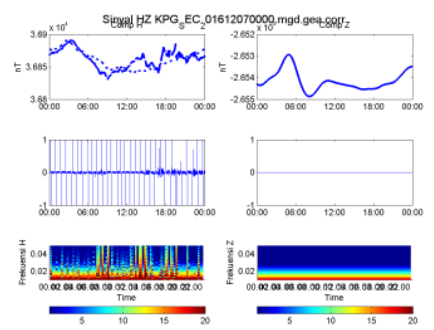

Gambar 6. Data spektrum 7 Desember 2016

Dari Gambar 6. dapat dilihat bahwa data spektrum tanggal 7 Desember tidak baik untuk digunakan sehingga secara tidak langsung azimuth pada tanggal 7 Desember tereleminasi.

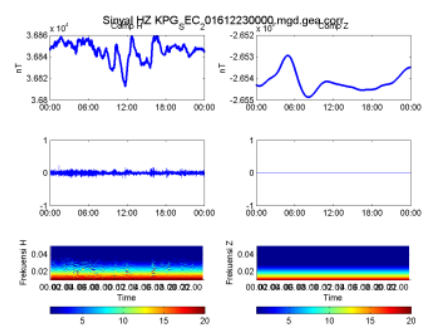

Gambar 7. Data spektrum 23 Desember 2016

Dari Gambar 7. dapat dilihat bahwa data spektrum tanggal 23 Desember tidak ada masalah sehingga azimuth pada tanggal 23 Desember dapat diperhitungkan sebagai azimuth untuk event gempa 5 Januari 2017.

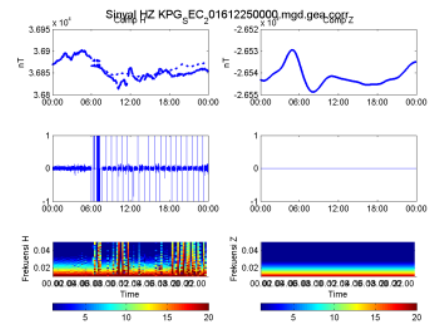

Gambar 8. Data spektrum 25 Desember 2016

Dari Gambar 8. dapat dilihat bahwa data spektrum tanggal 25 Desember tidak baik untuk digunakan sehingga secara tidak langsung azimuth pada tanggal 25 Desember tereleminasi.

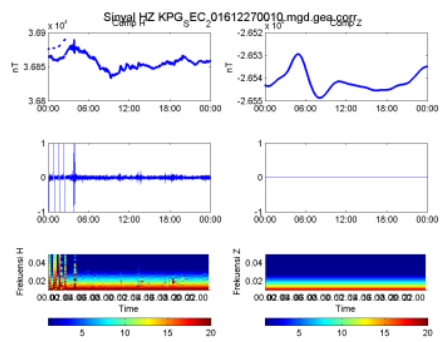

Gambar 9. Data Spektrum 27 Desember 2016

Dari Gambar 9. dapat dilihat bahwa data spektrum tanggal 23 Desember terdapat error dari pukul 00.00 hingga kurang lebih pukul 05.00. apabila nilai azimuth keluar pada rentan waktu 00.00 hingga 05.00 , nilai azimuth diabaikan. Dikarenakan Azimuth yang digunakan pada tanggal 27 
Desember ini adalah pukul 09.00, tidak masalah untuk digunakan sehingga azimuth pada tanggal 27 Desember dapat diperhitungkan sebagai azimuth untuk event gempa 5 Januari 2017.

Selanjutnya nilai polarisasi $\mathrm{Z} / \mathrm{H}$ dari azimuth yang dipilih dibandingkan dengan data DST. DST dapat dikatakan adanya badai magnetik ketika nilai DST melebihi dari -50 . Dikarenakan dari grafik DST tidak menunjukkan adanya aktivitas badai magnetik sehingga kedua azimuth dapat digunakan sebagai prekursor. Akan tetapi, Setiap event gempa hanya memiliki 1 prekursor. Oleh karena itu, untuk menentukannya adalah dengan kembali membandingkan azimuth yang sekiranya paling mengarah ke event gempa. Penulis pun akhirnya memilih azimuth pada tanggal 23 Desember yang dijadikan sebagai prekursor karena dianggap paling mendekai titik event gempa (Gambar 11).

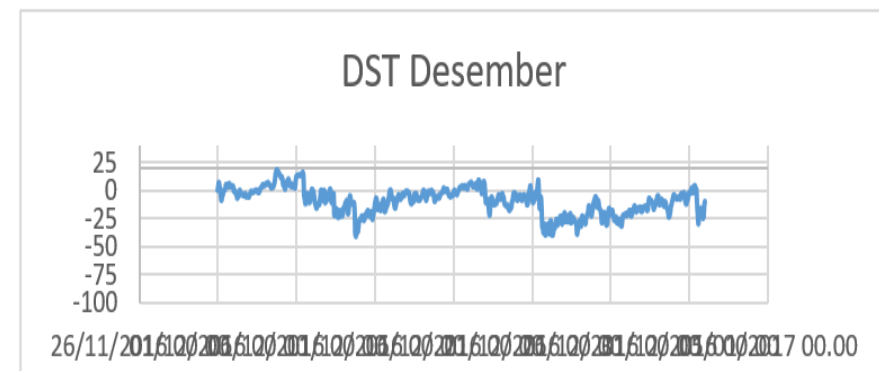

Gambar 10. Grafik DST Desember 2016

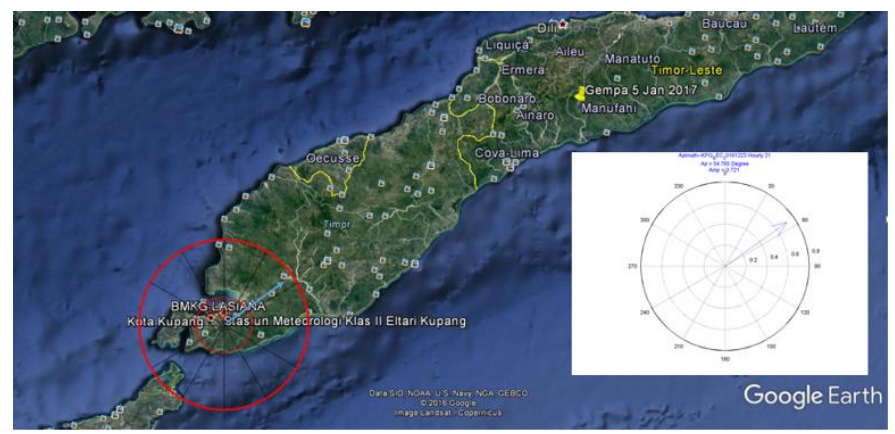

Gambar 11. Peta Event Gempa 5 Januari yang sudah dipasang Azimuth

\section{B. Penentuan Persamaan Magnitudo Gempabumi}

Kini sudah diketahui prekursor gempabumi dari setiap event gempa yang diteliti, sehingga dapat ditentukan polarisasi $\mathrm{Z} / \mathrm{H}$, jarak hypocenter, dan magnitudo setiap event gempa (Tabel 1). Yang mana nilai polarisasi $\mathrm{Z} / \mathrm{H}$ bisa didapatkan dari pengolahan data, sedangkan jarak hypocenter serta magnitudo didapatkan dari data event gempabumi yang mana dari data event gempabumi kita dapat mengetahui kedalaman dan jarak epicenter kemudian dapat kita phytagoraskan untuk mendapatkkan jarak hypocenter.

Tabel 1.

Nilai polarisasi $\mathrm{Z} / \mathrm{H}$, Hypocenter dan Magnitudo

\begin{tabular}{cccc}
\hline \hline Event & Z/H & Hypo & Mag \\
\hline 15-Nov & 2.141 & 211.2091 & 4 \\
21-Nov & 2.207 & 188.7351 & 5 \\
22-Nov & 3.58 & 66.6403 & 4.3 \\
22-Nov & 2.961 & 68.76756 & 4.6 \\
\hline \hline
\end{tabular}

\begin{tabular}{lccc}
\hline \hline 07-Des & 2.236 & 179.5979 & 4.2 \\
11-Des & 3.39 & 131.8957 & 4 \\
15-Des & 3.39 & 129.6662 & 4 \\
05-Jan & 2.574 & 252.9877 & 4 \\
20-Jan & 2.574 & 209.0193 & 4.1 \\
30-Jan & 2.631 & 211.5217 & 4.3 \\
21-Feb & 2.167 & 200.2326 & 4 \\
16-Mar & 3.636 & 78.7376 & 4.1 \\
18-Mar & 4.261 & 97.7031 & 4.1 \\
20-Mar & 3.074 & 88.58431 & 4.4 \\
22-Mar & 3.212 & 91.86633 & 4.6 \\
01-Apr & 3.212 & 167.4148 & 4.4 \\
15-Apr & 8.648 & 268.7709 & 4.5 \\
\hline \hline
\end{tabular}

Data pada Tabel 1. dianalisis secara statistik untuk menentukan persamaan regresi linier magnitudo gempabumi dengan menggunakan software minitab. Saat diolah pertama kali dihasilkan sebuah persamaan regresi linier akan tetapi persamaan tersebut tidak signifikan. Persamaan dapat dikatakan signifian apabila $\mathrm{P}$ value dari persamaan tersebut mendekati nol dan tidak melebihi dari 0,05. Dikarenakan hasil persamaan tidak signifikan, diolah kembali akan tetapi dilakukan penyeleksian data kembali dengan mengeleminasi data yang dianggap tidak selaras dengan data lainnya dengan melihat scatterplot seperti gambar 12.

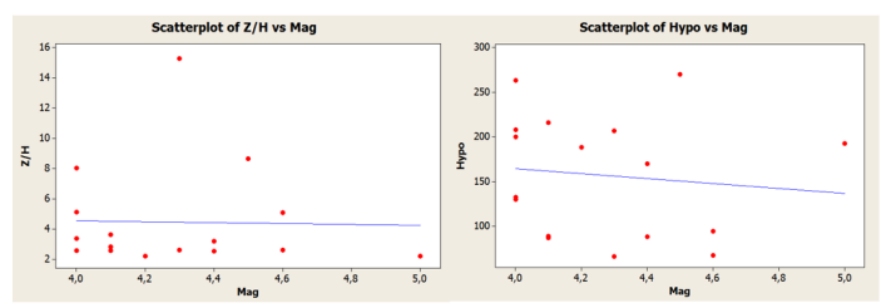

Gambar 12. Scatterplot Z/H vs Magintudo dan Hypocenter vs Magnitudo

Setelah diseleksi didapatkan 9 data yang lanjut ke pengolahan untuk mendapatkan persamaan regresi linier magnitudo dan didapatkan persamaan sebagai berikut.

Mag $=4,36+0,0805 \frac{Z}{H}-0,00201$ Hypo

Akan tetapi meskipun persamaan tersebut sudah signifikan dengan error selisih hasil $\pm 0.3 \mathrm{M}$, dikarenakan ketika digunakan data $\mathrm{M}=5$ hasil yang didapatkan sangatlah jauh dari $M=5$. Hal ini dikarenakan dalam ditentukannya persamaan, data yang digunakan hanya dalam lingkup $\mathrm{M}=4$.

Hasil ini menunjukkan bahwa penggunaan persamaan magnitudo masih belum bisa diterapkan pada daerah Kupang dengan nilai magnitudo diatas $4 \mathrm{M}$. Namun tidak menutup kemungkinan metode ini dapat diterapkan, hanya saja pada penelitian ini terhalang keterbatasan data sehingga tidak dapat dilanjutkan kembali.

\section{KESIMPULAN/RINGKASAN}

Dari penelitian yang sudah dilakukan didapatkan kesimpulan sebagai berikut: 
1. Persamaan dirasa kurang tepat dikarenakan tidak dapat digunakan pada data magnitudo yang nilai $\mathrm{M}>4$.

2. Persamaan magnitudo gempabumi masih belum bisa diterapkan pada daerah Kupang dengan nilai magnitudo diatas $4 \mathrm{M}$

\section{DAFTAR PUSTAKA}

[1] O. A. Molchanov and M. Hayakawa, "Generation of ULF electromagnetic emissions by microfracturing," Geophys. Res. Lett., vol. 22, no. 22, pp. 3091-3094, Nov. 1995.

[2] M. Molchanov, O.A., Kulchitsky, A.V., Hayakawa, "Inductive seismo- electromagnetic effect in relation to seismogenic ULF emission. In: Hayakawa, M., Molchanov, O.A. (Eds.), Seismo
Electromagnetics (Lithosphere- Atmosphere-Ionosphere Coupling," TERRAPUB, pp. 153-162, 2002.

[3] J. . Fenoglio, M.A., Johnston, M.J.S., Byerlee, "Magnetic and electric fields associated with changes in high pore pressure in fault zones: Application to the Loma Prieta ULF emissions," pp. 12951$12958,1995$.

[4] S. Mizutani, H., Ishido, T., Yokokura, T., Ohnishi, "Electrokinetic phenomena associated with earthquakes," pp. 365-368, 1976.

[5] J. . Jouniaux, L., Pozzi, "Streaming potential and permeability of saturated sandstones under triaxial stress: Consequences for electrotelluric anomalies prior to EQs,” pp. 10197-10209, 1995.

[6] K. Yumoto, "Generation and propagation mechanisms of lowlatitude magnetic pulsations - A review," pp. 79-105, 1986.

[7] H. J. Chi, P.J., Russell, C.T., Lee, G., Hughes, W.J., Singer, "A synoptic study of Pc 3,4 waves using the Air Force Geophysics Laboratory magnetometer array,” pp. 13215-13224, 1996. 